\title{
WOOD ANATOMICAL STUDIES REVEAL TAXONOMIC RELATIONSHIPS, ENVIRONMENTAL INFLUENCE AND PULP POTENTIAL IN FOUR TAXA OF Mussaenda (RUBIACEAE) GROWN IN NIGERIA
}

\author{
Felix I. Nwafor ${ }^{1,2 *}$, Ugochukwu Igwe ${ }^{2}$, Chidi Ogbonna ${ }^{3}$, Godswill Ajuziogu ${ }^{2}$, Maria O Nwosu $^{2}$
}

${ }^{1}$ Department of Pharmacognosy and Environmental Medicine, University of Nigeria, Nsukka

${ }^{2}$ Department of Plant Science and Biotechnology, University of Nigeria, Nsukka, Nigeria

${ }^{3}$ Department of Environmental Resources Management, Abia State University, Uturu, Nigeria

Received - August 31, 2020; Revision - November 20, 2020; Accepted - October 08, 2020

Available Online - February 27, 2021

DOI: http://dx.doi.org/10.18006/2021.9(1).100.107

\begin{tabular}{l} 
KEYWORDS \\
Mussaenda \\
Rubiaceae \\
Wood anatomy \\
Taxonomy \\
Paper and pulp \\
Environment \\
\hline
\end{tabular}

\begin{abstract}
Current study was carried out to assess the taxonomic, ecological significance, and paper making potential of four taxa of Mussaenda L. (Rubiaceae) viz., M. elegans, M. erythrophylla, M. philippica var. aurorae, and M. 'Dona Aurora' through wood anatomical studies. Each of the taxa was collected from its natural region of provenance in two different ecological zones (Derived Savanna and Tropical Rainforest) of Nigeria. Observations from different planes of sections were made and wood maceration was carried out for fibre morphology. Absent to scanty paratracheal axial parenchyma, septate fibres, pitted vessels, storied heterocellular rays, and simple perforation plates were common features in all taxa. However, multiseriate and wider rays distinguished the exotic species from the indigenous species, and the semi-diffuse porous wood pattern was a unique feature in M. 'Dona Aurora'. Quantitative data showed considerable variations in case of fibre lengths among the four taxa i.e. M. elegans, M. erythrophylla, M. philippica var. aurorae, and M. 'Dona Aurora' and was recorded $0.80 \pm 0.02 \mu \mathrm{m}$, $0.70 \pm 0.05 \mu \mathrm{m}, 0.65 \pm 0.03 \mu \mathrm{m}$ and $0.64 \pm 0.04 \mu \mathrm{m}$ respectively. These observations showed that all species belong to Wood Type II of Rubiaceae and support their inclusion in the Tribe Mussaendeae and Order Ixoroideae. The influence of environmental factors was evident in the significant elongation of wood vessels of samples collected from more humid areas, but with no significant effect on their papermaking potential. More so, M. "Doña Aurora", had general scores, would be most suitable for pulp and paper making.
\end{abstract}

* Corresponding author

E-mail: felix.nwafor@unn.edu.ng (Felix I. Nwafor)

Peer review under responsibility of Journal of Experimental Biology and Agricultural Sciences.

Production and Hosting by Horizon Publisher India [HPI] (http://www.horizonpublisherindia.in/).

All rights reserved.
All the articles published by Journal of Experimental Biology and Agricultural Sciences are licensed under a Creative Commons Attribution-NonCommercial 4.0 International License Based on a work at www.jebas.org.

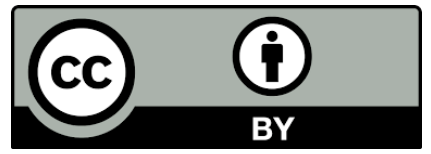




\section{Introduction}

The differences in the processes of species development are depending on the functional differences in plant species growing in diverse environmental settings (Sharon \& Siobhan, 2016). The stress from the environment poses diverse effects on the tissues and organs within a plant which leading to different responses to stress among the tissues and through the developmental lifetime of a plant (Nicotra et al., 2010; Sharon \& Siobhan, 2016). The response of plants to environmental stress varies and it mostly depends on the intensity and duration of stress, as well as the differences in organization and developmental stage of the species (Chelli-Chaabouni, 2014). Under continuous stress conditions, while non-perennial species shorten their biological cycle as a mechanism of averting the effect of the stress, species with long vegetative cycle (woody species) will have to developed specific mechanisms to withstand likely damages as a result of extreme environmental conditions (Chelli-Chaabouni, 2014).

Because of this, plants over time using anatomical strategies and adaptations have been able to accomplish various functions in different environmental conditions (Wimmer et al., 2002; Fichtler \& Worbes, 2012; Campbell et al., 2016). Consequently, physiological processes also resulting in the change in the anatomical structure of tissues and organs (Kramer \& Kozlowski 1960). Plant anatomical study is, therefore, necessary to gain an understanding of the processes of growth and water and nutrient transport in trees (Kramer \& Kozlowski 1960; Campbell et al., 2016). It is also an important source of traits to make distinctions between species. Furthermore, comparative anatomical studies provide useful information to ecological phylogenetic studies, since it is possible to evaluate structural changes due to different environmental stresses (Schweingruber et al., 2014; Campbell et al., 2016).

Systematic wood anatomy of the Rubiaceae has been investigated by several researchers (Jansen et al., 1996; Jansen et al., 1999; Jansen et al., 2001) and has already contributed to the grouping of the family into several subgroups. The genus Mussaenda is one of the largest genera in the Rubiaceae, represented by over 200 species, distributed mostly in the forests of the tropical old world (Govaerts et al., 2006; Shimpale et al., 2009; Nwafor et al., 2019). The Mussaenda's (commonly called the Queen of the Philippines or Flag bush) is a genus of tropical evergreen shrubs and scrambling climbers that have grown for their long-lasting showy flowers (Ogbu, 2011). In the tropical African's centre of diversity, there are 35 species of Mussaenda, of which six are currently grown in Nigeria (Bridson \& Verdcourt, 1988; Robbrecht, 1988; Ogbu, 2011). There is scanty information on the proper identification and classification of the cultivated garden Mussaendas in Nigeria and the available information shows mixed up in the identities as almost all the distinct ornamental species are grown here have been regarded as 'Queen of Philippines' (Nwafor et al.,2019). This study was carried out to evaluate the taxonomic and environmental significance of wood anatomical features in the delineation of four taxa of Mussaenda (M. elegans, $M$. erythrophylla, M. philippica var. aurorae, and M. 'Dona Aurora') and assess their suitability in pulp and paper production.

\section{Materials and Methods}

\subsection{Collection and Sampling}

Fresh wood samples of M. elegans, M. erythophylla, M. "Dona Aurora" and M. "Dona Luz", of the same age bracket, were collected from their natural regions of provenance. Each sample was collected from two different locations (rainforest and derived savanna areas - Uyo and Nsukka respectively within southern Nigeria). Their proper identification was carried out in the Department of Plant Science and Biotechnology, University of Nigeria, Nsukka using relevant literature and taxonomic keys. The samples for wood maceration were oven-dried while those for sectioning were preserved in FAA until use.

\subsection{Preparation of wood for anatomical studies}

Transverse sections (TS), tangential longitudinal sections (TLS), and radial longitudinal sections (RLS) of the wood were made using a Reichert sledge microtome following the procedures of Johansen (1950) and Nwosu (2006). The sectioned materials, which were between 10 and 15 microns, were picked from the tip of the microtome knife into separate Petri dishes containing $70 \%$ alcohol and labeled appropriately. Thereafter these sections were transferred into different staining jars and stained with $1 \%$ Safranin for 5 mins. The Safranin solution was dehydrated and the sections were rinsed thrice in distilled water before they were counterstained in $1 \%$ fast green solution for 5 minutes and again rinsed thrice with absolute alcohol. The stained sections were transferred into staining jars containing absolute ethanol and xylene in the ratio of 1:1 and washed until they became clear. Pure xylene was finally used to clear the sections further and then placed on standard slides using Canada balsam as a mounting agent. These sections were covered with coverslips and then allowed to dry. The prepared slides were viewed under a light Olympus Tokyo (Japan No.271961) microscope at $\times 40$ and $\times 100$, photomicrographs of the specimens were taken with a Moticam 2.0 camera attached to the microscope.

\subsection{Preparation of wood for fibre morphology}

Schulze's method as described by Sharma et al.(2005) and Ajuziogu et al. (2019) was used for maceration. The bark of the oven-dried stem discs was excised from the wood after which the wood was cut into tiny bits of about match stick size $(0.1-0.3 \times 4$ $\mathrm{cm})$. They were then placed into well-labeled test tubes to which 
Table 1 Comparison of Anatomical Variables of the TS of mature stems of the four Mussaenda taxa

\begin{tabular}{|c|c|c|c|c|}
\hline Tissue component & M. elegans & M. erythrophylla & M. "Doña Aurora" & M. "Doña Luz" \\
\hline Rays & Rays abundant & Rays abundant & Rays abundant & Rays abundant \\
\hline Vessels & $\begin{array}{l}\text { Abundant; diffuse } \\
\text { porous; solitary to radial } \\
\text { multiples of } 2-7 \text { cells }\end{array}$ & $\begin{array}{l}\text { Abundant; diffuse } \\
\text { porous; solitary to radial } \\
\text { multiples of } 2-7 \text { cells }\end{array}$ & $\begin{array}{l}\text { Scanty; semi-diffuse } \\
\text { porous; solitary to radial } \\
\text { multiples of } 2-3 \text { cells }\end{array}$ & $\begin{array}{l}\text { Abundant; diffuse } \\
\text { porous; solitary to radial } \\
\text { multiples of } 2-7 \text { cells }\end{array}$ \\
\hline Axial parenchyma & $\begin{array}{l}\text { Absent to scanty } \\
\text { paratracheal }\end{array}$ & $\begin{array}{l}\text { Absent to scanty } \\
\text { paratracheal }\end{array}$ & $\begin{array}{l}\text { Absent to scanty } \\
\text { paratracheal }\end{array}$ & $\begin{array}{l}\text { Absent to scanty } \\
\text { paratracheal }\end{array}$ \\
\hline
\end{tabular}

Table 2 Comparison of Anatomical Variables of the TLS of mature stems of the four Mussaenda taxa

\begin{tabular}{|c|c|c|c|c|}
\hline Tissue component & M. elegans & M. erythrophylla & M. "Doña Aurora" & $M$. "Doña Luz" \\
\hline Rays & $\begin{array}{l}\text { Rays are predominantly } \\
\text { biseriate and narrower }\end{array}$ & $\begin{array}{l}\text { Rays are predominantly } \\
\text { biseriate and narrower }\end{array}$ & $\begin{array}{l}\text { Rays are predominantly } \\
\text { multiseriate and wider }\end{array}$ & $\begin{array}{l}\text { Rays are predominantly } \\
\text { multiseriate and wider }\end{array}$ \\
\hline Fibre & $\begin{array}{c}\text { Fibres are septate and } \\
\text { abundant }\end{array}$ & $\begin{array}{c}\text { Fibres are septate and } \\
\text { abundant }\end{array}$ & $\begin{array}{c}\text { Fibres are septate and } \\
\text { abundant }\end{array}$ & $\begin{array}{c}\text { Fibres are septate and } \\
\text { abundant }\end{array}$ \\
\hline Vessels & Pitted & Pitted & Pitted & Pitted \\
\hline Perforation plate & Simple & Simple & Simple & Simple \\
\hline
\end{tabular}

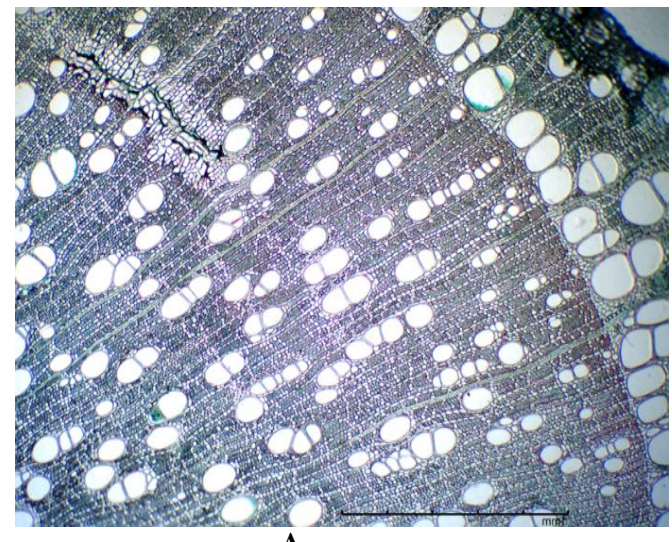

A

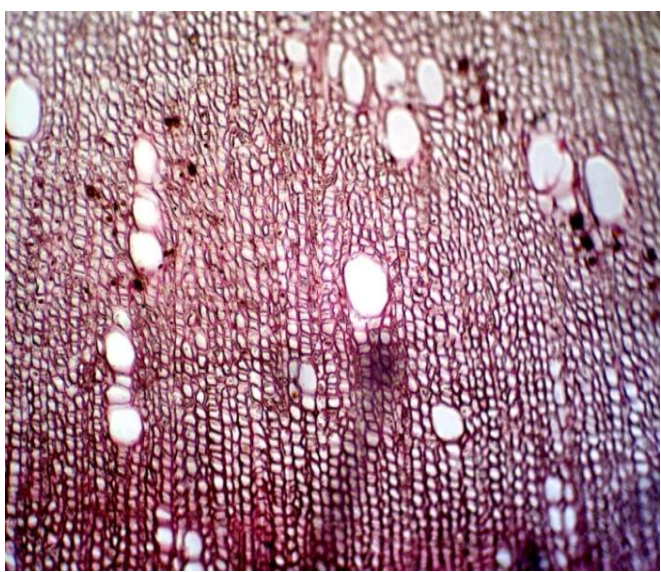

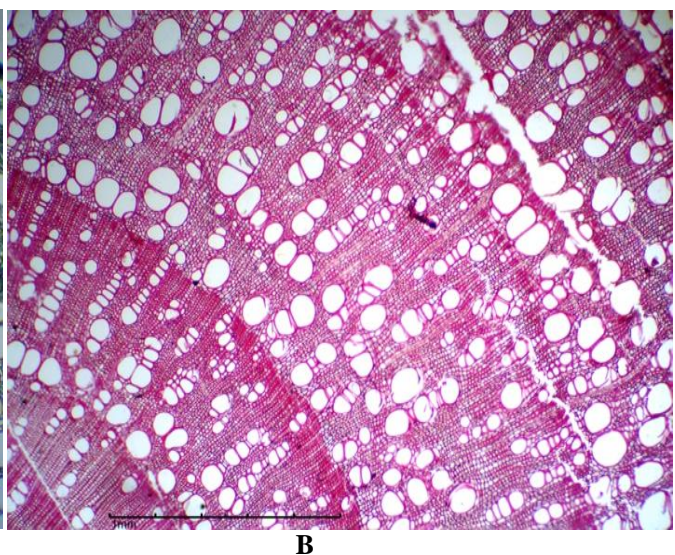

B

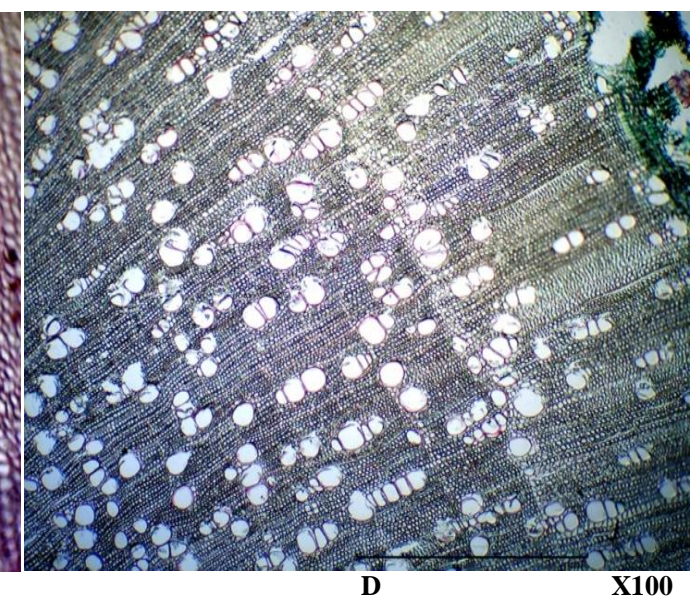

Figure 1 Transverse sections of the mature stems of M.elegans (A); M.erythrophylla(B); M. "Doña Aurora" (C) and M. "Doña Luz" (D) 
Table 3 Comparison of Anatomical Variables of the RLS of mature stems of the four Mussaenda taxa

\begin{tabular}{|ccccc|}
\hline Tissue component & M. elegans & M. erythrophylla & M. "Doña Aurora" & $M$. "Doña Luz" \\
\hline \multirow{2}{*}{ Rays } & $\begin{array}{c}\text { Heterocellular: presence } \\
\text { of both upright and } \\
\text { procumbent cells }\end{array}$ & $\begin{array}{c}\text { Heterocellular: presence } \\
\text { of both upright and } \\
\text { procumbent cells }\end{array}$ & $\begin{array}{c}\text { Heterocellular: presence } \\
\text { of both upright and } \\
\text { procumbent cells }\end{array}$ & $\begin{array}{c}\text { Heterocellular: presence } \\
\text { of both upright and } \\
\text { procumbent cells }\end{array}$ \\
\hline \multirow{2}{*}{ Vessels } & $\begin{array}{c}\text { Vessels present with } \\
\text { vessel ray pitting }\end{array}$ & $\begin{array}{c}\text { Vessels present with } \\
\text { vessel ray pitting }\end{array}$ & $\begin{array}{c}\text { Vessels present with } \\
\text { vessel ray pitting }\end{array}$ & $\begin{array}{c}\text { Vessels present with } \\
\text { vessel ray pitting }\end{array}$ \\
\hline
\end{tabular}

Table 4 Comparison of quantitative wood anatomical parameters of the four taxa of Mussaenda

\begin{tabular}{|c|c|c|c|c|}
\hline Parameter & M. elegans & M. erythrophylla & $M$. "Doña Aurora" & M. "Doña Luz" \\
\hline Fiber length $(\mu \mathrm{m})$ & $796.00 \pm 22.47^{\mathrm{a}}$ & $703.00 \pm 45.17^{\mathrm{ab}}$ & $648.00 \pm 29.43^{b}$ & $642.00 \pm 42.05^{\mathrm{b}}$ \\
\hline Fiber diameter $(\mu \mathrm{m})$ & $18.72 \pm 0.92^{\mathrm{a}}$ & $14.82 \pm 0.85^{\mathrm{b}}$ & $19.63 \pm 0.69^{\mathrm{a}}$ & $13.65 \pm 0.77^{b}$ \\
\hline FLD $(\mu \mathrm{m})$ & $10.27 \pm 0.48^{\mathrm{b}}$ & $9.49 \pm 0.43^{\mathrm{b}}$ & $13.78 \pm 0.43^{\mathrm{a}}$ & $9.10 \pm 0.40^{\mathrm{b}}$ \\
\hline FCWD $(\mu \mathrm{m})$ & $4.68 \pm 0.36^{\mathrm{b}}$ & $4.68 \pm 0.40^{\mathrm{b}}$ & $5.85 \pm 0.42^{\mathrm{a}}$ & $4.29 \pm 0.39^{\mathrm{b}}$ \\
\hline Vessel length $(\mu \mathrm{m})$ & $24.85 \pm 0.95^{\mathrm{c}}$ & $33.18 \pm 3.17^{\mathrm{b}}$ & $32.46 \pm 2.21^{\mathrm{b}}$ & $44.41 \pm 2.39^{\mathrm{a}}$ \\
\hline $\mathrm{VPD}(\mu \mathrm{m})$ & $1.27 \pm 0.06^{\mathrm{b}}$ & $1.31 \pm 0.05^{\mathrm{b}}$ & $6.45 \pm 0.25^{\mathrm{a}}$ & $1.16 \pm 0.03^{\mathrm{b}}$ \\
\hline Vessel density $\left(\mathrm{mm}^{2}\right)$ & $24.69 \pm 1.40^{\mathrm{c}}$ & $60.33 \pm 3.15^{\mathrm{a}}$ & $11.45 \pm 0.09^{d}$ & $40.31 \pm 1.78^{\mathrm{b}}$ \\
\hline Raunkier ratio & $0.93 \pm 0.08$ & $1.00 \pm 0.09$ & $0.84 \pm 0.05$ & $0.95 \pm 0.08$ \\
\hline Flexibility coefficient (\%) & $55.81 \pm 2.13$ & $66.69 \pm 3.59$ & $71.18 \pm 2.48$ & $69.07 \pm 3.36$ \\
\hline Slenderness ratio & $44.37 \pm 2.43$ & $48.60 \pm 2.51$ & $33.39 \pm 1.51$ & $48.01 \pm 2.34$ \\
\hline
\end{tabular}

Means with different letters as superscript along the column are significantly different at $\mathrm{p} \leq 0.05$; FLD $=$ fibre lumen diameter; FCWD $=$ fibre cell wall diameter; VPD = vessel pore diameter

Table 5 Comparison of quantitative wood anatomical parameters of the four taxa of Mussaendaacross the two locations

\begin{tabular}{|c|c|c|c|c|c|c|c|c|}
\hline \multirow{2}{*}{ Parameter } & \multicolumn{2}{|c|}{ M. elegans } & \multicolumn{2}{|c|}{ M. erythrophylla } & \multicolumn{2}{|c|}{$M$. "Doña Aurora" } & \multicolumn{2}{|c|}{ M. “Doña Luz" } \\
\hline & DS & $\mathrm{RF}$ & DS & $\mathrm{RF}$ & DS & $\mathrm{RF}$ & DS & $\mathrm{RF}$ \\
\hline Fiber length $(\mu \mathrm{m})$ & $781 \pm 36.56$ & $811 \pm 27.30$ & $671 \pm 58.20$ & $735 \pm 70.70^{*}$ & $613 \pm 44.60$ & $\begin{array}{c}683 \pm \\
37.36^{*}\end{array}$ & $570 \pm 28.36$ & $714 \pm 74.23 *$ \\
\hline $\begin{array}{l}\text { Fiber diameter } \\
\qquad(\mu \mathrm{m})\end{array}$ & $18.72 \pm 1.33$ & $18.72 \pm 1.33$ & $14.30 \pm 1.24$ & $15.34 \pm 1.19^{*}$ & $18.72 \pm 1.08$ & $20.54 \pm 0.82$ & $12.48 \pm 1.08$ & $14.82 \pm 1.03$ \\
\hline FLD $(\mu \mathrm{m})$ & $10.40 \pm 0.67$ & $10.14 \pm 0.72$ & $9.88 \pm 0.65$ & $9.10 \pm 0.58$ & $13.52 \pm 0.65$ & $14.04 \pm 0.57$ & $9.10 \pm 0.69$ & $9.10 \pm 0.43$ \\
\hline FCWD $(\mu \mathrm{m})$ & $4.42 \pm 0.55$ & $4.94 \pm 0.47$ & $4.42 \pm 0.55$ & $4.94 \pm 0.61$ & $5.46 \pm 0.61$ & $6.24 \pm 0.57$ & $3.65 \pm 0.42$ & $4.94 \pm 0.61$ \\
\hline $\operatorname{VL}(\mu \mathrm{m})$ & $25.42 \pm 1.19$ & $24.28 \pm 1.53$ & $32.56 \pm 4.47$ & $33.80 \pm 4.72 *$ & $32.11 \pm 3.02$ & $32.82 \pm 3.39$ & $43.26 \pm 3.61$ & $45.57 \pm 3.27 *$ \\
\hline $\operatorname{VPD}(\mu \mathrm{m})$ & $1.25 \pm 0.10$ & $1.29 \pm 0.05$ & $1.16 \pm 0.05$ & $1.47 \pm 0.06$ & $6.36 \pm 0.30$ & $6.53 \pm 0.40$ & $1.11 \pm 0.04$ & $1.21 \pm 0.05$ \\
\hline $\mathrm{VD}\left(\mathrm{mm}^{-2}\right)$ & $26.25 \pm 2.04$ & $23.13 \pm 1.88$ & $61.88 \pm 5.06$ & $58.78 \pm 3.98$ & $11.65 \pm 0.11$ & $11.26 \pm 0.12$ & $41.88 \pm 2.47$ & $38.75 \pm 2.60$ \\
\hline $\mathrm{RR}$ & $0.86 \pm 0.11$ & $1.01 \pm 0.11$ & $0.89 \pm 0.10$ & $1.11 \pm 0.15$ & $0.79 \pm 0.07$ & $0.88 \pm 0.06$ & $0.81 \pm 0.09$ & $1.08 \pm 0.12$ \\
\hline $\mathrm{FC}(\%)$ & $56.62 \pm 3.14$ & $55.01 \pm 3.02$ & $71.18 \pm 4.26$ & $62.20 \pm 5.63$ & $73.59 \pm 4.20$ & $68.77 \pm 2.66$ & $74.08 \pm 3.79$ & $64.05 \pm 5.25$ \\
\hline SR & $43.51 \pm 3.62$ & $45.23 \pm 3.43$ & $48.09 \pm 3.18$ & $49.12 \pm 4.06$ & $33.21 \pm 2.37$ & $33.56 \pm 2.01$ & $47.09 \pm 2.42$ & $48.92 \pm 4.14$ \\
\hline
\end{tabular}

* = Significantly higher at $\mathrm{p} \leq 0.05 ; \mathrm{FLD}=$ fibre lumen diameter; FCWD $=$ fibre cell wall diameter; VPD $=$ vessel pore diameter; VD =

vessel density; All parameter in $\mu \mathrm{m}$ except vessel density $\left(\mu \mathrm{m}^{2}\right)$

maceration solution (containing $2 \mathrm{~g}$ of $5 \%$ potassium chlorate and $10 \mathrm{ml}$ of nitric acids) was added. The tubes were placed in a fume cupboard and allowed to react until the lignin and the middle lamella of the chips dissolved. The appearance of white tissue mass at the base of the test tubes indicated completion of the maceration process. The residual acid was decanted off and distilled water was poured into the test tubes to dissolve the tissues and stop further chemical reaction. The test tubes were left to stand for 24 hours before the macerated tissues were recovered and stored in micro bottles. $10 \%$ glycerine was added to remove air bubbles while $70 \%$ formalin and $1 \%$ Safranin solution served as preservative and stain respectively.

\subsection{Measurement of wood anatomical parameters}

A light Olympus Tokyo (Japan No.271961) microscope to which an ocular diameter was fitted was used for the measurement of vessel length (VL), vessel pore diameter (VPD), fibre length (FL), fibre diameter (FD), fibre lumen diameter (FLD) and fibre cell wall diameter (FCWD. A total of 30 replicate measurements were taken to improve the accuracy of the results.

\subsection{Statistical analyses}

Data collected across the taxa were subjected to analysis of variance (ANOVA) while significant means were separated using Duncan's New Multiple Range Test. Data across the ecological zones were subject to an independent sample T-test using IBM SPSS ver. 20. 


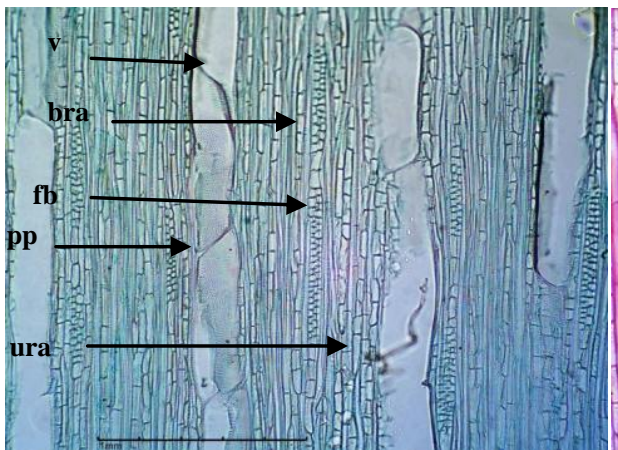

A

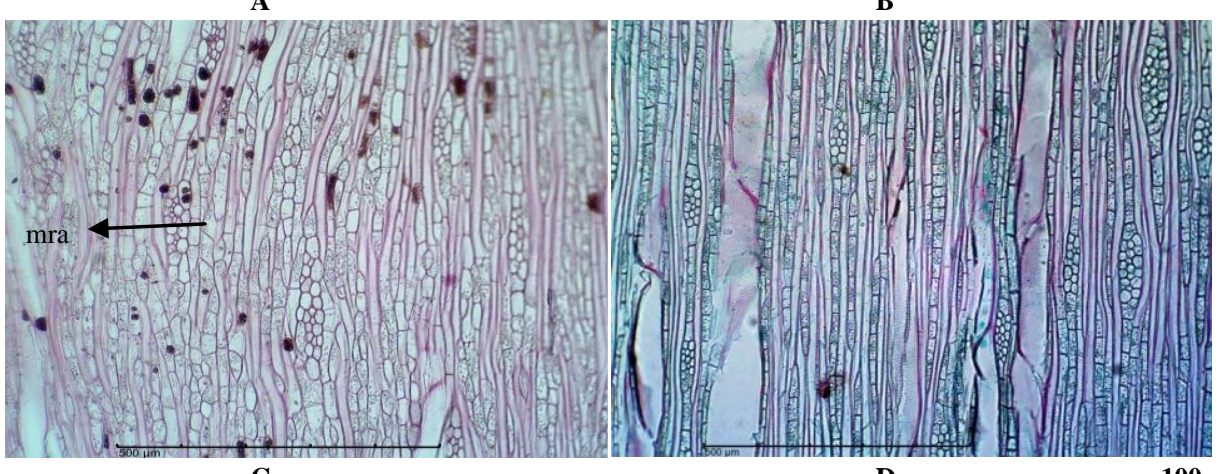

C

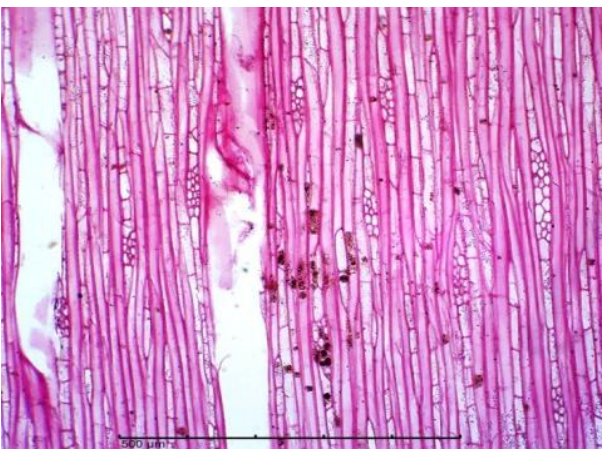

$\mathbf{x 1 0 0}$

Figure 2 TLS of the mature stems of M. elegans (A); M. erythrophylla(B); M. "Doña Aurora" (C) and M. "Doña Luz" (D); v = vessel; $\mathrm{bra}=$ biseriate ray; $\mathrm{fb}=$ fibre; $\mathrm{pp}=$ perforation plate; $\mathrm{ura}=$ uniseriate ray; $\mathrm{mra}=$ multiseriate ray

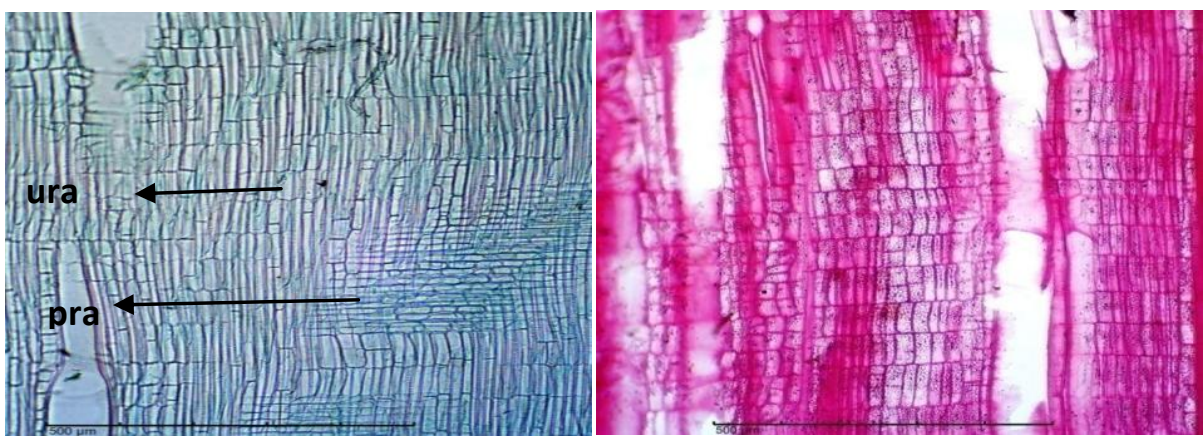

A

B

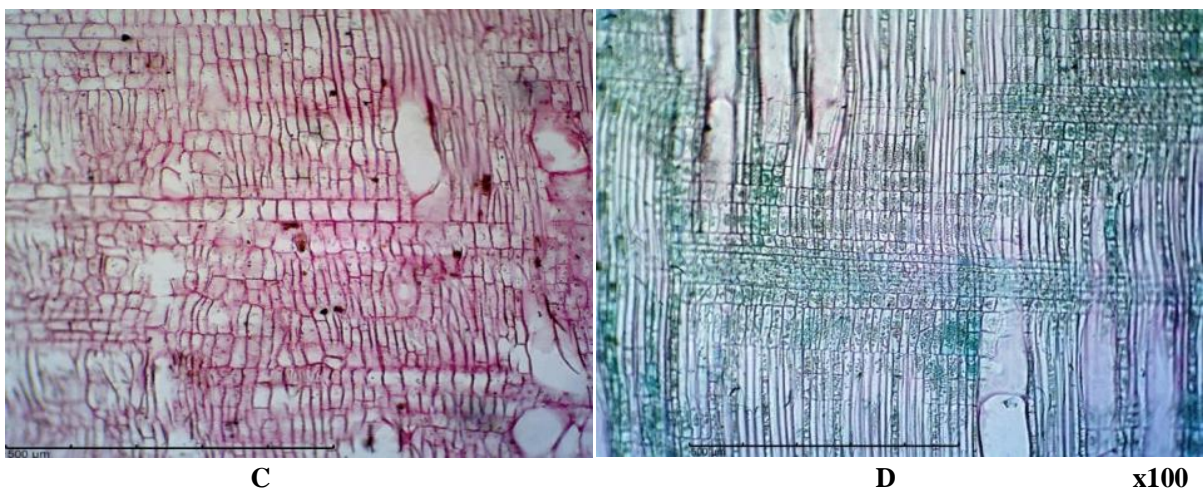

Figure 3 RLS of the mature stems of M.elegans (A); M.erythrophylla (B); M. "Doña Aurora" (C) and M. "Doña Luz" (D); ura= upright ray; pra $=$ procumbent ray

Journal of Experimental Biology and Agricultural Sciences http://www.jebas.org 


\section{Results}

3.1 Comparative Wood Anatomical Variables in the Four Taxa of Mussaenda

The comparative wood anatomical variables as seen in transverse sections (TS), tangential (TLS) longitudinal sections, and radial longitudinal sections (RLS) are shown in Tables 1 - 3 and Plates 1 -3 respectively. All the taxa had abundant rays that are diffuse, porous with $2-7$ solitary to radial multiples cells except $M$. 'Doña Aurora'. The axial parenchymas ranged from absent to scanty paratracheal with septate fibres, vessels that are pitted, solitary, or in radial multiples of 2 - 4 or more and the rays are heterocellular, while the perforation plates are simple.

The mean anatomical variables among the four taxa of Mussaenda studied varied significantly at $\mathrm{P} \leq 0.05$ (Table 4). Fibre length, fibre diameter, fibre lumen diameter, and fibre cell wall diameter, ranged from $642 \mu \mathrm{m}-796 \mu \mathrm{m}, 13.65 \mu \mathrm{m}-19.36 \mu \mathrm{m}, 9.10 \mu \mathrm{m}-$ $13.78 \mu \mathrm{m}$ and $4.29 \mu \mathrm{m}-5.58 \mu \mathrm{m}$ respectively, with M. "Doña Luz" recording almost the lowest values in these parameters. The vessel length, vessel pore diameter, and vessel density were significantly highest in $M$. 'Doña Luz', $M$. 'Doña Aurora', and $M$. erythrophylla, respectively (Table 4). The T-test revealed that the fibre length was significantly longer in $M$. erythrophylla, $M$. "Doña Aurora" and M. "Doña Luz" plants growing in the rainforest compared to the derived savanna. Similarly, $M$. erythrophylla from the rainforest had wider fibres, while vessel length also was the longest in M. erythrophylla, and $M$. "Doña Luz" from the rainforest (Table 5).

\section{Discussion}

The systematic wood anatomy of the Rubiaceae has been investigated by several researchers (Jansen et al., 1996; Jansen et al., 1999; Jansen et al., 2001) and has already contributed to the grouping of the family into several subgroups. The result of the wood anatomical study in these four taxa of Mussaenda showed that they all belongs to Wood Type II of Rubiaceae (axial parenchyma are absent to scanty paratracheal; fibres are septate, vessels are pitted, solitary or in radial multiples of $2-4$ or more; rays heterocellular and perforation plates are simple) and supports their inclusion in the Tribe Mussaendeae and Order Ixoroideae (Jansen et al., 2001). Additionally, diffuse porous wood was evidenced in all the taxa except for M. 'Doña Aurora' which showed semi-diffuse porous wood. The quantitative study of the wood anatomical variables, however, showed considerable variations among the four taxa of Mussaenda. The climbing and weakly erect species (M. elegans and M. erythrophylla) had shorter fibres and narrower fibre diameter, fibre lumen diameter, and fibre cell wall diameter than the erect taxa ( $M$. 'Doña Aurora' and M. 'Doña Luz'). However, vessel density, vessel length and vessel pore diameter were lowest in $M$. "Doña Aurora" and highest in M. erythrophylla. This agrees with Bass et al. (2004) who reported that vessel diameter is proportional to the size of a tree or shrub and smaller trees have narrower vessels while higher vessel density is associated with weaker wood species. Similarly, Bass (1986) also reported that smaller wood species have higher vessel density.

Plants respond to changing environmental conditions through dynamic anatomical adjustments in their wood formation processes, which affect their vessel size, vessel pore size, and vessel density (Wimmer et al., 2002; Fichtler \& Worbes, 2012). This was evident from this study as the samples collected from the relatively wet study location (Rainforest - Uyo) had longer vessels. The shorter vessels of the relatively dry (Derived Savanna - Nsukka) species could be an adaptive feature to improve conductivity in the wood (Wheeler et al., 2007). Even though not significantly different $(\mathrm{P}>0.05)$, the samples from relatively dry study locations had denser vessels than those from the Rainforest area. This is another adaptive measure to improve conductivity as water transport capacity is mainly defined by vessel size and density, especially in situations where water availability is a determinant factor for plant growth (Wheeler et al., 2007).

The level of efficiency by a wood species to be utilized in pulping is greatly determined by its fibre characteristics (Ajuziogu et al., 2019). Following the classification that fibres above $1.6 \mathrm{~mm}$ in length are termed long fibre (Ogunkunle \& Oladele, 2008; Ajuziogu et al., 2019), the fibre across the studied four taxa were short. Longer fibre had been reported to produce higher tear resistance in the paper (Oluwadare \& Ashimiyu, 2007), however, fibres from the museanda taxa are likely to produce paper with low tear resistance. This does not rule out the possible use of these plants for papermaking since a commonly used plant for papermaking (G. arborea) had been reported to have short fiber $(0.8887 \pm 0.0281 \mathrm{~mm})$ (Ajuziogu et al., 2019). Another considerable factor in papermaking is the fibre diameter and lumen diameter in that large diameter with broad lumen diameter guarantees enhanced collapsibility and bonding in the process of paper production (Okereke, 1962; Oluwadare \& Ashimiyu, 2007; Ajuziogu et al., 2019). Therefore M. "Doña Aurora" would be a better candidate for utilization as compared to other taxa.

The significance of the varied fibre dimensions in papermaking relies on the fibre derived values (Runkel ratio, Coefficient of Flexibility, and Slenderness ratio) more than the absolute dimensions. Transforming these dimensions into ratios provides better information about the fibres and the kind of pulp and paper to be made from them (Oladele, 1991). The lower the Runkel ratio especially when it is less than 1 the better for papermaking 
as papers made from fibre with low Runkel ratios are less porous and flexible (Chittenden \&Rotibi, 1962; Dutt et al., 2009; Ogunleye et al., 2017; Ajuziogu et al., 2019). Therefore, $M$. "Doña Aurora" is considered fit for paper-making. Considering the coefficient of flexibility which determines the tensile strength property of the fibre, M. "Doña Aurora" is still considered best for papermaking because the higher the value of the coefficient, the more flexible and tensile is the fibre (Oluwadare \& Ashimiyu, 2007).

\section{Conclusion}

The result of the wood anatomical study in these four taxa of Mussaenda showed that they all belong to Wood Type II of Rubiaceae and supports their inclusion in the Tribe Mussaendeae and Order Ixoroideae. Based on the established results, the two exotic species were distinguished from others by having multiseriate and wider rays. The influence of environmental factors was evident in the significant elongation of wood vessels of samples collected from more humid areas, but with no significant effect on their paper-making potential. More so, $M$. "Doña Aurora", from general scores, would be most suitable for pulp and paper making.

\section{References}

Ajuziogu GC, Ojua EO, Aina DO (2019) Comparative Papermaking Potentials of Three Species from the Verbenaceae and Lamiaceae Family. Asian Journal of Research in Botany 2(4): 1-5.

Bass P (1986) Ecological patterns of xylem anatomy. Paleobiology 19: 487 - 498.

Bass P, Ewers FW, Davis SD, Wheeler EA (2004) Evolution of xylem physiology. In: Hamsley AR, Poole I (Eds.), The Evolution of Plant Physiology. Elsevier Academic Press, UK.

Bridson D, Verdcourt B (1988) Flora of Tropical East Africa: Rubiaceae (Part 2). Rotterdam, Balkema.

Campbell G, Rabelo GR, Cunha M (2016) Ecological significance of wood anatomy of Alseispickelii Pilg. \& Schmale (Rubiaceae) in a tropical dry forest. Acta Botanica Brasilica 30(1): 124-130.

Chelli-Chaabouni A (2014) Mechanisms and adaptation of plants to environmental stress: A case of woody species. In: Ahmad P, Wani M (Eds), Physiological Mechanisms and Adaptation Strategies in Plants Under Changing Environment. Springer, New York, United States of America.

Chittenden AE, Rotibi JO (1962) Studies on the Suitability of Nigerian Raw Materials for Pulp Making, Gmelina arborea.
Research Report 17, Federal Ministry of Commerce and Industry.

Dutt D, Upadhyaya JS, Singh B, Tyagi CH (2009) Studies on Hibiscus cannabinus and Hibiscus sabdariffa as an alternative pulp blend for softwood: An optimization of kraft delignification process. Industrial Crops and Products 29: 16-26.

Fichtler E, Worbes M (2012) Wood anatomical variables in tropical trees and their relation to site conditions and individual tree morphology. IAWA Journal 33: 119-140.

Govaerts R, Frodin DG, Ruhsam M, Bridson DM, Davis AP (2006) World Checklist and Bibliography of Rubiaceae. The Trustees of the Royal Botanic Gardens, Kew.

Jansen S, De Block P, Beeckman H, Smets E (1999) Systematic wood anatomy of the Pavetteae (Rubiaceae, Ixoroideae). Systematic Geography 68: 113-133.

Jansen S, Lens F, Ntore S, Piesschaert F, Robbrecht E, Smets E (2001) Contributions to the systematic wood anatomy of the Rubioideae (Rubiaceae). Journal of Plant Research 114: 269289.

Jansen S, Robbrecht E, Beeckman H, Smets E (1996) Gaertnera and Pagamea: genera within the Psychotrieae or constituting the tribe Gaertnereae? A wood anatomical and palynological approach. Acta Botanika 109: 466- 476.

Johansen DA (1950) Plant Microtechnique. McGraw-Hill Book Company, New York.

Kramer PJ, Kozlowski TT (1960) Physiology of Trees. McGraw Hill Book Co., Inc., New York.

Nicotra AB, Atkin OK, Bonser SP, Davidson AM, Finnegan EJ, Mathesius U, Poot P, Purugganan MD, Richards CL, Valladares F, van Kleunen M (2010) Plant phenotypic plasticity in a changing climate. Trends Plant Science 15: 684-692.

Nwafor FI, Nwosu MO, Nwafor AZ (2019) Taxonomic and ecological significance of foliar epidermal characters in four taxa of Mussaenda L. (Rubiaceae) in Nigeria. Annual Research \& Review in Biology 32(5): 1-12.

Nwosu MO (2006) Preparation of botanical slides. In: Inyang, NM, Nwosu MO, Ivoke N (Eds). Manual of Laboratory Techniques in Biology. University of Nigeria Press Ltd Nsukka, Nigeria.

Ogbu JU (2011) Ornamental Mussaenda spp for Nigeria's Gardens and Landscape Environment. Proceedings of the 45th 
Annual Conference of the Agricultural Society of Nigeria (ASN), 24th-28th Oct., Usmanu Danfodiyo University, Sokoto, 45:316 319

Ogunkunle ATJ, Oladele FA (2008) Structural dimensions and paper making potentials of wood in some Nigeria species of Ficuscarica L. (Moraceae). Advances in Natural and Applied Sciences 2(3): 103-111.

Ogunleye BM, Fuwape JA, Oluyege AO, Ajayi B, Fabiyi JS (2017) Evaluation of fiber characteristics of RicinodedronHeudelotii(Baill, Pierre ex Pax) for pulp and paper making. International Journal of Science and Technology 6 (1): 634-641.

Okereke OO (1962) Studies on the Fibre Dimensions of Some Nigerian Timber and other Raw Materials. Part 1 Research Report 16. Federal Minister of Commerce and Industry, Lagos, Nigeria, Pp. 40.

Oladele FA (1991) Essentials and Applications of wood Anatomy. J. Olatiregun (Nig). Company Ltd., Ibadan.

Oluwadare AO, Ashimiyu OS (2007) Wood properties and selection for rotation length in Caribean pine (Pinus caribeaMorelet) grown in Afaka, Nigeria. American-European Journal of Agriculture and Environmental Science 2 (4): 359 363.
Robbrecht E (1988) Tropical woody Rubiaceae. Characteristics, features and progressions. Contribution to a new subfamilial classification. Opera Botanica Belgica 1271.

Schweingruber FH, Riha P, Dolezal J (2014) Variation in stem anatomical characteristics of Campanuloideae species in relation to evolutionary history and ecological preferences. PLoS ONE 9(2): e88199. doi:10.1371/journal.pone.0088199.

Sharma SK, Rao RV, Shukla SR, Kumar P, Sudheendra R, Sujatha M, Dubey YM (2005) Wood quality of coppiced Eucalyptus tereticornis for value addition. IAWA Journal 26: 137147.

Sharon BG, Siobhan MB (2016) Plant developmental responses to climate change. Developmental Biology 419 (1): 64-77.

Shimpale VB, Yadav SR, Babu CR (2009) A review of the genus Mussaenda (Rubiaceae) from great Nicobar Island, India, including a new species. Rheedea19 (1 \& 2): 53-57.

Wheeler EA, Bass P, Rodgers S (2007) Variations in dicot wood anatomy: a global analysis based on the InsideWood database. IAWA Journal 28: $229-248$.

Wimmer R, Downes GM, Evans R, Rasmussen G, French J (2002) Direct effects of wood characteristics on pulp and paper handsheet properties of Eucalyptus globulus. Holzforschung 56 (3): $244-250$.

Journal of Experimental Biology and Agricultural Sciences http://www.jebas.org 